\title{
Importance of physiotherapy/nursing multidisciplinary integration about update newborn position in the neonatal intensive care unit
}

\author{
Importância da integração multidisciplinar fisioterapia/ \\ enfermagem na atualização sobre posicionamento do recém- \\ nascido na unidade de terapia intensiva neonatal
}

\begin{abstract}
Vanessa da Silva Neves Moreira Arakaki, Alana Monteiro de Oliveira, Trícia Bogossian, Viviane Saraiva de Almeida, Gustavo Dias da Silva, Halina Cidrini Ferreira*
\end{abstract}

Maternidade Escola da Universidade Federal do Rio de Janeiro (UFRJ), Rio de Janeiro, RJ, Brazil

\begin{abstract}
Introduction: The high-risk newborns may require long periods of hospitalization until they reach clinical stability for hospital discharge. Avoiding babies to be in only one body position may be an effective way to cause respiratory and neuro-psycho-motor benefits, comfort and preventing pressure ulcers. Objectives: This study investigated the impact of physiotherapy/nursing integration in update on body positioning of the newborn in the Neonatal Intensive Care Unit. Methods: A questionnaire was administered to nurses and nursing technicians of the neonatal unit of Maternity School of UFRJ and nurses of the Advanced Course in Neonatal Nursing from the same institution. Two classes were taught by the physical therapist of the sector and the questions answered before and after these lessons. It was also a brief characterization of
\end{abstract}

* VSNM: grad., e-mail: vanessaneves.ufrj@yahoo.com.br AMO: grad., e-mail: alanaufrj@hotmail.com TB: specialist, e-mail: enfgustavo@yahoo.com.br VSA: MSc student, e-mail: vivianesaraiva@hotmail.com GDS: MSc student, e-mail: enfgustavo@yahoo.com.br HCF: PhD, e-mail: hcidrini@uol.com.br 
professional participants of the study. We used the Student's t test to compare the correct answers before (PRE) and after (POST) the classes, considering $\mathrm{p}<0.05$. Results: There was a significant increase in the degree of knowledge of nurses and nursing technicians when compared the responses before (nurses: 68.8\%; technicians: $70.1 \%$ ) and after classes (nurses: $78.4 \%$; technicians: $88.9 \%$ ). The nurses were less than five years of graduated $(45 \%)$ and little time of professional experience in neonatology $(60 \%)$. Forty-seven percent of technicians had less than five years of training and $82 \%$ had less than 10 years of experience. Conclusion: The use of training by the nursing staff was significant, showing the importance of multidisciplinary approach and the integration of knowledge in the search for a humanized and effective care.

Keywords: Neonatal intensive care. Patient positioning. Patient care team.

\section{Resumo}

Introdução: Recém-nascidos de risco podem necessitar de longas internações até atingirem estabilidade clínica para a alta hospitalar. Evitar mantê-los em uma só postura é um dos cuidados que devem ser realizados a fim de beneficiar a respiração, o desenvolvimento neuropsicomotor e o conforto e prevenir escaras por pressão. Objetivos: Verificar o impacto da integração fisioterapia/enfermagem na atualização sobre posicionamento do recém-nascido no leito da UTI Neonatal. Métodos: Foi aplicado um questionário aos enfermeiros e técnicos de enfermagem da unidade neonatal da Maternidade Escola da UFRJ e aos enfermeiros do curso de aperfeiçoamento em enfermagem neonatal da mesma instituição. Duas aulas foram ministradas pela fisioterapeuta do setor e as perguntas, respondidas antes e após tais aulas. Foi realizada também uma breve caracterização profissional dos participantes do estudo. Utilizou-se o teste t Student para comparar os acertos antes (PRÉ) e após (PÓS) as aulas, considerando-se $p<0.05$. Resultados: Houve um aumento no grau de conhecimento dos enfermeiros e técnicos de enfermagem ao serem comparadas as respostas antes (enfermeiros: 68,8\%; técnicos: 70,1\%) e após as aulas (enfermeiros: 78,4\%; técnicos: 88,9\%). Os enfermeiros apresentaram em sua maioria menos de cinco anos de graduados (45\%) е pouco tempo de experiência profissional em neonatologia (60\%). Entre os técnicos, 47\% tinham menos de cinco anos de formação e 82\%, possuía menos de 10 anos de experiência. Conclusão: 0 aproveitamento do treinamento pela equipe de enfermagem foi significativo, mostrando a importância da atuação multidisciplinar e da integração do conhecimento na busca por um cuidado humanizado, técnico e eficaz.

Palavras-chave: Terapia intensiva neonatal. Posicionamento do paciente. Equipe de assistência ao paciente.

\section{Introduction}

Newborns (NB) hospitalized in neonatal intensive care units (NICU), regardless of gestational age and the disease they present, they are experiencing noxious stimulus by invasive interventions that they are submitted (1). Most of babies at risk are premature, however, full-term or post term NB with also appear in the units various diseases or syndromes.

Premature newborns are every baby born with gestational age less than 37 completed weeks. According to the gestational age at birth, preterm NB can be categorized as extremely preterm ( $<28$ weeks), very preterm ( $\geq 28-<32$ weeks) and moderate preterm ( $\geq$ $32-<37$ weeks) $(1,2)$. It is estimated that 15 million
NB are born prematurely each year and the 10 countries with the highest preterm birth rates including Brazil, the United States, India and Nigeria, showing prematurity as a global problem (1).

Excluding prematurity, the other NB hospitalized in NICU are affected by several diseases, including metabolic (hypoglycemia, hyperbilirubinemia, inborn errors of metabolism), neurological (congenital malformations of the nervous system, apnea, encephalopathy, among others), cardiac, renal, respiratory (meconium aspiration syndrome, transient tachypnea, pneumonia, bronchiolitis, diaphragmatic hernia). In all cases, the babies are vulnerable and they are at risk. Therefore, it is essential that they receive specific care from the health team $(1,3)$. 
Commonly, NB hospitalized in NICU have different adaptation to the extra-uterine environment, evidenced by changes in primitive reflexes, global hypotonia, spontaneous movement deficit against gravity and immaturity in organizational systems. In addition, premature have a higher frequency of alterations in their development $(4,5)$, delayed weight and height, mental, hearing impairment, visual impairment, language difficulties, cardiovascular, respiratory and attention deficits when compared to newborns at term $(5,6)$.

NB at risk may need prolonged hospitalization periods until they reach maturity and minimal clinical stability to receive secure hospital discharge. Therefore, multidisciplinary care should be performed to minimize the impact of the absence of family contact and environmental changes they are submitted $(6,7)$. One of the important care for hospitalized NB in NICU is the decubitus change, that is, avoiding to keep them in only one posture. The correct positioning is beneficial both to the respiratory system, preventing accumulation of secretions, optimizing the function and thoracoabdominal biomechanics and facilitating lung expansion (8-12) as for the psychomotor and behavioral development and providing greater comfort preventing pressure ulcers (1, 13-15).

Through a proper positioning, it is possible to facilitate the neuromuscular processing associated with flexor patterns that help in the acquisition of antigravity movements, and promoting guidance of the middle and largest state organization line. The use of towels or sheets in the form of rolls, provides adequate containment, establishing limits and support for the NB body and adequacy of positioning in the incubator in order to provide self-organization and allow the facilitation of movements the baby already performed in the utero, as take hands to their mouth or face, hand contact with the other hand and body. The use of these measures is to promote postural stability, biomechanical development and behavioral stability of the newborn (14-17).

Inadequate positioning for long time, the very global hypotonia of the premature baby and the action of gravity contribute to postural abnormalities and changes in respiratory mechanics $(8,9,11)$.

The clinical condition of the babies determines whether they are able to perform certain positions and decubitus changes will be tolerated. The smaller the premature and the greater clinical severity, the smaller should be the number of handlings. It is very important awareness and training of the NICU staff about the adequacy of postures, as to when to use each one and the optimal duration of each position, since each one has its own benefits and restrictions $(10,11,18,19)$.

The NICU nursing team is responsible for general care of the babies during all day, including hygiene, administration of medication, monitoring vital signs and decubitus changes (20). Physiotherapy professionals contribute to the restoration of the respiratory and motor function, also including the correct positioning in bed in order to perpetuate the results obtained with therapy. However, in many neonatal units, physiotherapists do not stay on duty at all times, limiting their activities (21).

In this context, the nursing team has a fundamental role for the correct positioning of the babies, since this team stays longer in contact with the NB and takes the watching function in the perpetuation of their good clinical condition. Therefore, the measurement of the knowledge level of the nursing staff about the correct positioning of the babies is relevant and essential, since the concepts and correlations between care and comfort are widely studied by this team $(20,22,23)$. The relations of different positions and breathing physiology and psychomotor development of newborns are more focused by the physiotherapy team (24-30). In this way, each area has its own specific knowledge and multidisciplinary integration of content making care most comprehensive and extensive.

This study aims to evaluate the impact of physiotherapy/nursing multidisciplinary integration in the update on the newborn positioning in NICU beds.

\section{Methods}

The project is in line with Resolution number 466/2012 of the National Health Council and its complementary and the Code of Medical Ethics from 1988 (Articles 122 to 130) and it was approved by the Research Ethics Committee of the Maternity School of the Federal University of Rio de Janeiro (CEP/MEUFRJ) under number: 08/2011.

It is a cross-sectional and prospective study with quantitative approach. The study sample was randomly selected by conglomerate and it was composed of all the nurses of the NICU from the Maternity School 
of the Federal University of Rio de Janeiro (nursing technicians and nurses), and all nurses from neonatal nursing improvement course of the unit in August and September 2011 (total of 38 individuals).

A questionnaire about positioning of premature babies was created, applied in two stages: before and after of two sequential classes (one theoretical and one with practical demonstration) with one of the physiotherapists of Neonatology Service of the Maternity School of the Federal University of Rio de Janeiro, held in one day, lasting about 40 minutes each. The questionnaire contained 16 objective questions and issues related to the subjects taught in class were addressed. The lessons were about the physiological effects of each posture, including psychomotor and respiratory systems, and the advantages and disadvantages of each posture and the importance of the correct positioning. Classes were held in NICU of the Maternity School of the Federal University of Rio de Janeiro. A practical demonstration was performed using materials from the unit as rolls made with towels, cloth diapers and swaddling-cloth.

The questionnaire also included a brief description of the professional participants, including: time since graduation/graduate, professional experience time in neonatology, place of training and graduate courses in the area (nurses). The training participants were asked to complete the research and received information through a free and informed consent. The results analysis had an organization, summarization and description of the data set. The results of the questions were presented in percentage of the correct answers before (PRE) and after (POST) classes, according to an answer key based on current literature and widely discussed among researchers.

Statistical analysis of the general percentage of correct answers before (PRE) and after (POST) the update classes was performed with the statistical software SigmaStat (Jandel Scientific, San Rafael, CA, USA). Data normality and homogeneity of variances were tested using the Kolmogorov-Smirnov test with Lilliefors correction and Median Levene Test, respectively. Since both conditions were satisfactory, the data were compared by paired $t$ test, considering significant $\mathrm{p}<0.05$.

\section{Results}

There was a statistically increase in the knowledge level of nurses $(n=20)$ when comparing the percentage of correct answers before (68.8\%) and after classes $(78.4 \%)(p=0.002)$ (Figure 1A).

The nursing technicians $(\mathrm{n}=18)$ also showed a significant increase percentage of correct answers after classes (from $70.1 \%$ to $88.9 \%$ ) ( $p<0.001$ ) (Figure 1B). It should be noted that the percentage of correct answers before (PRE) the update classes was similar in both groups (PRE $68.8 \%$ in nurses and $70.1 \%$ in nursing technicians).

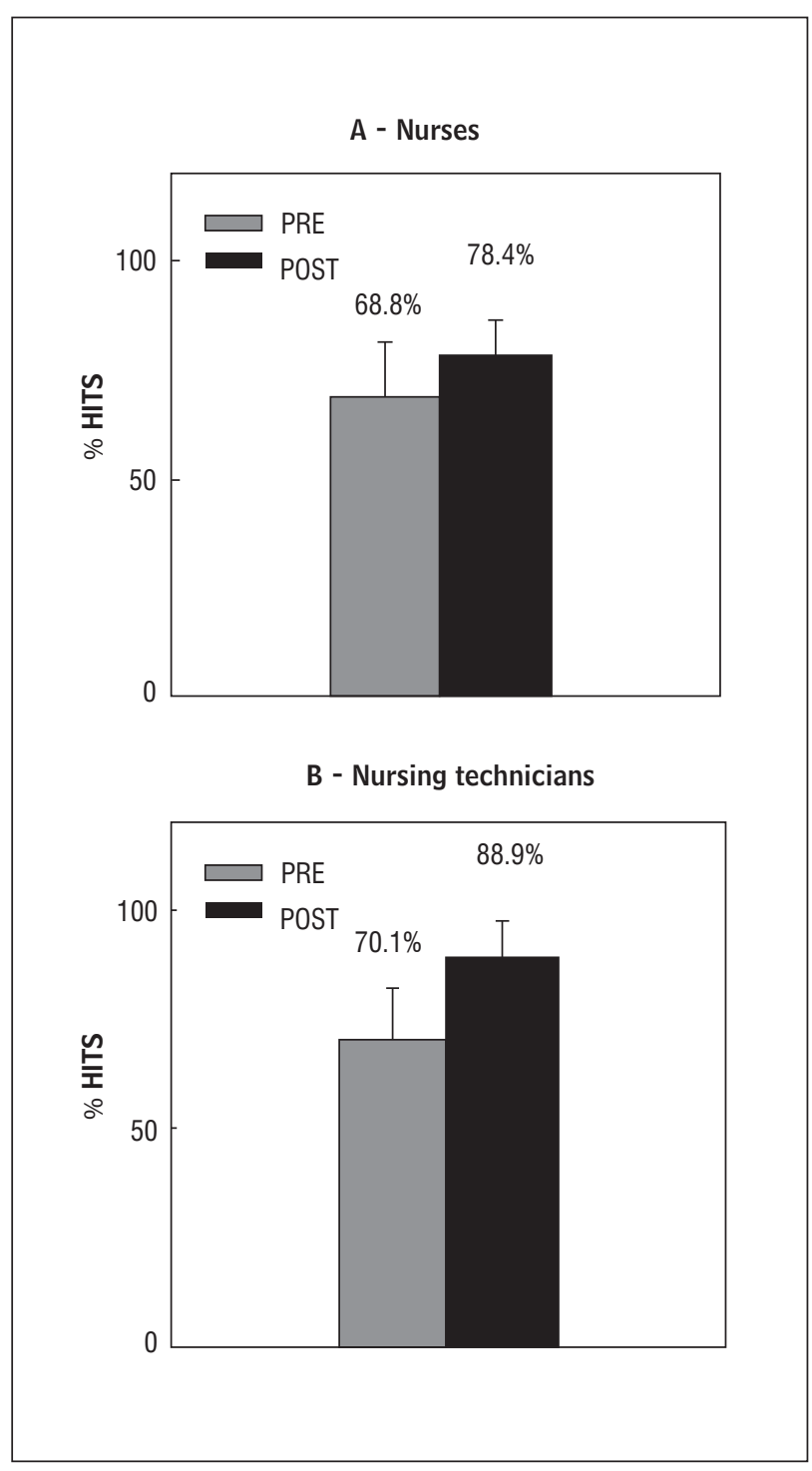

Figure $\mathbf{1}$ - Total percentage of correct answers obtained by the professionals, before and after classes about the newborn positioning in NICU

Note: A - General percentage of correct answers in nurses before (PRE) and after (POST) update classes. B - General percentage of correct answers in nursing technicians before (PRE) and after (POST) update classes. ${ }^{*} p<0.05$. NICU $=$ Neonatal Intensive Care Unit. 
The professional profile of the individuals interviewed was as follows: most of the graduates in nursing showed less than five years of graduation (45\%) and short time work experience in neonatology (60\% $<5 y$ ears). About their training, $60 \%$ of respondents did it in private institutions and $85 \%$ had graduate degrees in pediatrics and/or neonatology or related fields. It should be noted that the nurses interviewed were students of Neonatal Nursing under training and therefore the number of study participants of nurses was higher than nursing technicians, which is not common in any hospital staff. Regarding to nursing technicians, $47 \%$ had less than five years of training and $82 \%$ had less than 10 years of experience in neonatology. The characterization of the professional training of participants in the study is shown in Figure 2.

Table 1 shows individually, the percentage of correct answers in each question in both groups (nurses and nursing technicians).

\section{A - NURSES}
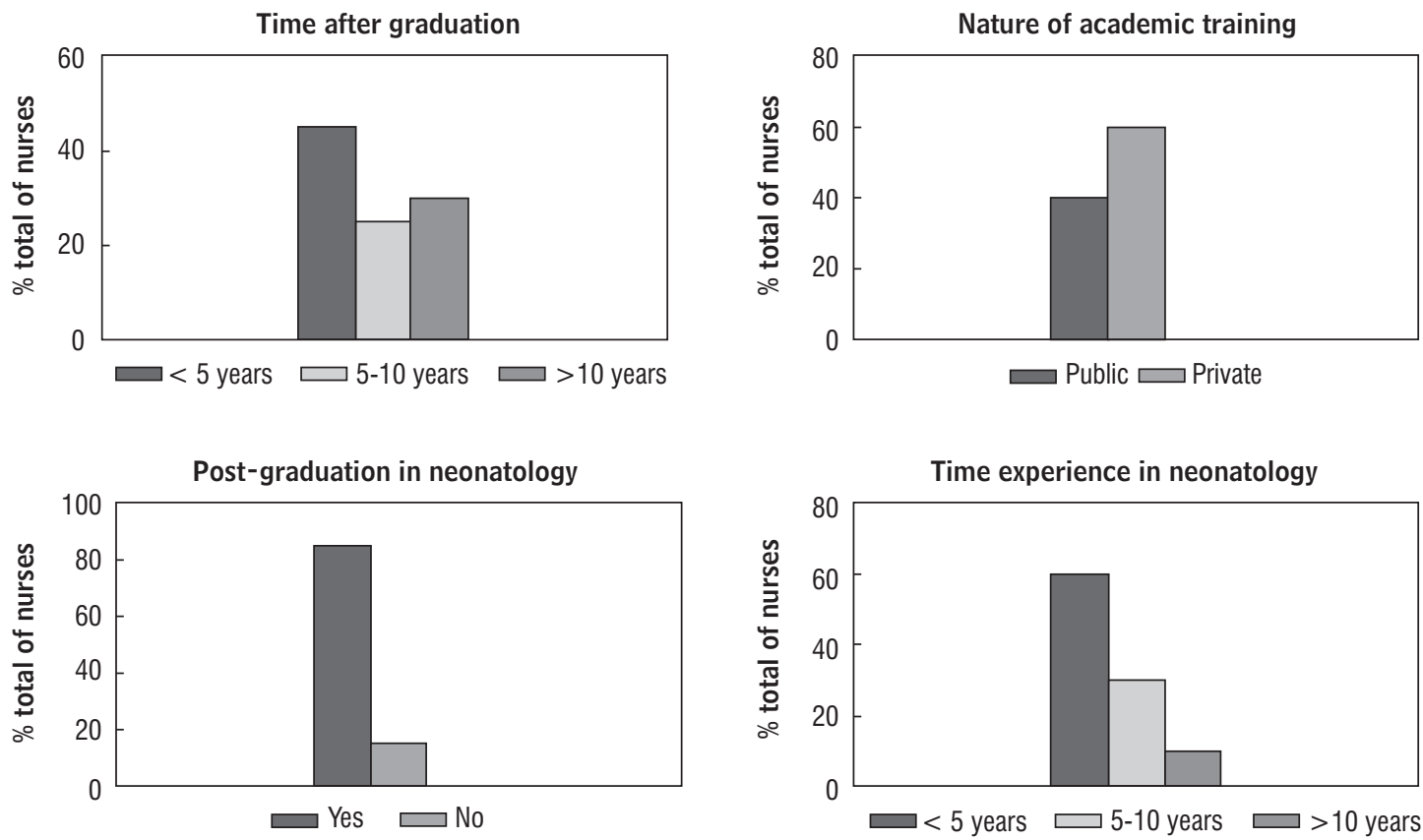

B - NURSING TECHNICIANS
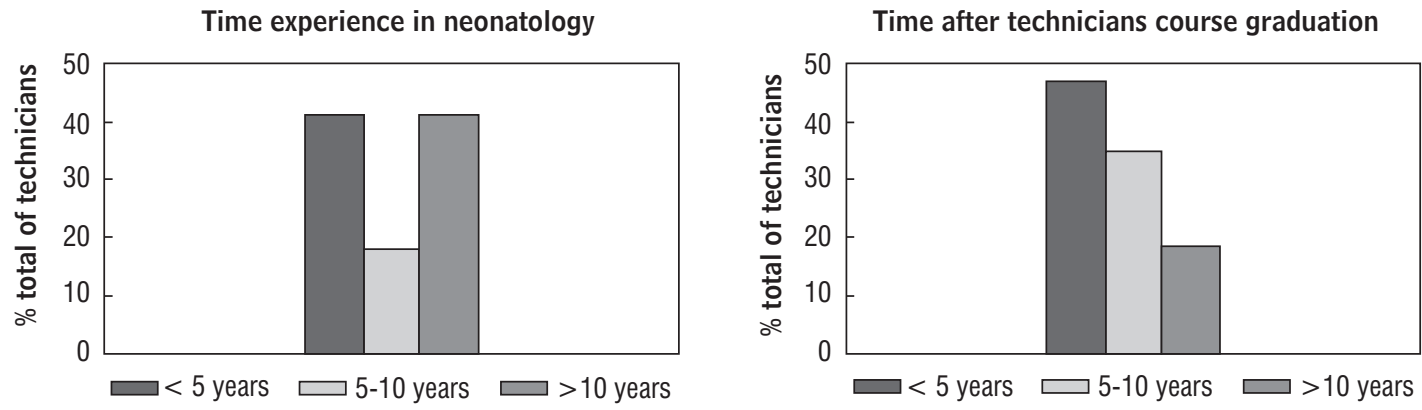

Figure 2 - Professional profile and training of the participants in this study Note: Values reflected in the training characteristics of nurses $(A)$ and nursing technicians (B) participants in this study. 
Table 1 - Percentage of correct answers in each question before (PRE) and after (POST) the update classes with the physiotherapist

\begin{tabular}{cccccc}
\hline Question & \multicolumn{2}{c}{$\%$ correct answers by } & nurses & & \% correct answers by nursing technicians \\
\cline { 2 - 3 } \cline { 5 - 5 } & Pre & Post & 70 & Pre & Post \\
\hline 1 & 65 & 100 & 61 & 83 \\
3 & 95 & 60 & 67 & 100 \\
4 & 60 & 80 & 50 & 78 \\
5 & 68 & 85 & 83 & 89 \\
6 & 65 & 80 & 50 & 67 \\
7 & 58 & 85 & 72 & 100 \\
8 & 70 & 70 & 83 & 94 \\
9 & 65 & 91 & 83 & 100 \\
10 & 85 & 85 & 78 & 100 \\
11 & 70 & 100 & 72 & 89 \\
12 & 100 & 95 & 89 & 100 \\
13 & 95 & 70 & 94 & 94 \\
14 & 55 & 95 & 50 & 72 \\
15 & 80 & 95 & 78 & 83 \\
16 & 70 & 100 & 72 & 72 \\
\hline
\end{tabular}

Note: PRE $=$ before the update classes; POST $=$ after the update classes. The values are only data description, without statistical comparison.

\section{Discussion}

This study showed a statistically significant increase in knowledge of the nursing staff (technicians and nurses) about the positioning in NICU beds after class update. It was also shown that most questions related to comfort and humanization $(2,9,11)$ had a percentage of correct answers than the others (Table 1), reflecting on respiratory and motor functions of newborn babies for the different postures used. In this way, it was possible to generate a broader and integrated view of this procedure widely used, through the combination of knowledge in these two very important teams and essential for a comprehensive and satisfactory care of the NB.

The nursing team showed more than $50 \%$ of correct answers of the questions before update class. Considering individual questions regarding the basic nursing care and proper positioning (14 and 16, for example), the percentage of correct answers before class was quite satisfactory (Table 1). It is noteworthy that this result was expected, since these issues are routinely trained and executed by the team (questions $11,14,20,23)$. On the other hand, questions such as 5 and 13 involving discussions of strategies to minimize respiratory distress, clinical severity and contraindications of some positions, have reported the lowest rates of correct answers (Table 1). It is important to remember that most of the study participants nurses had less than five years of professional experience in the field of neonatology $(60 \%$ - Figure $2 \mathrm{~A}$ ) and/or they were not part of the nursing staff of the Maternity School of the Federal University of Rio de Janeiro, since many of them were only participants of the Improvement Course and thus complementing their education. From this, the low percentages of correct answers of some questions from nurses could be explained. On the other hand, most of the nursing technicians perform their functions in more than six years neonatal intensive care (59\% - Figure 
2B), having a long period of clinical practice and continuous learning, which may explain the higher percentage of correct answers of questions they asked.

There is compatibility of results found with the descriptions of the nursing team performance. Questions related to the direct care of the newborn (hygiene, handling and administration of medicines, general control of permanent material and consumption, comfort, among others) are more focused and executed $(11,14,20,23)$. The nurse is the knowledge and work process holder of their area of responsibility and the other members (nursing assistants and technicians) are activities performers (23).

The creation of multi and interdisciplinary strategies involving the positioning in bed and the technical and correct use become imperative in NICU. The more several professional categories working in NICU discussing routines, exposing their private participation in each one, the better care become integrated and interdisciplinary to the newborns at risk.

Adequate positioning is a common routine and interferes in care humanization, motor development and respiratory baby characteristics. It is known that it facilitates the neuromuscular processing associating flexor patterns that assist in the acquisition of antigravity movement (15-17) enhancing the flexor patterns, preventing cranial deformities, increasing the midline orientation, promoting the state of the body organization and interfering in digestion. It also increases the chest wall compliance, mobilization of tidal volume and ensures a diaphragmatic contraction more efficient and with a better range of motion $(11,12,14,15,24-30)$. From this, all professionals working in NICU should have a thorough and extensive knowledge about the concepts involved in the correct positioning of the newborn and the guidelines governing such principles $(12,29,30)$.

This study provides a possible and easy proposal to perform involving the integration of key elements of two professional categories (in this case physiotherapy and nursing) present in NICU, with the objective of providing the baby a large, unfragmented care. The insertion of the physiotherapist knowledge added to the nursing knowledge originated interdisciplinary discussions that could enrich the knowledge of both professional groups. This demonstrates the urgent need for moments of reflection on the various health/disease processes of NICU also including the other professional categories attending the newborn (doctors, speech therapists, psychologists, music therapists). The fragmented understanding and no comprehension of the complexity of the newborn as a single subject can become an obstacle to the pursuit of all-round global humanization of care, taking into account the losses that may arise and commitments on child development.

Some capacity measures, study and discussion are commonly adopted by different teams integrating NICU. However, they are partial, isolated within each profession and practiced individually. The interdisciplinary practices, where care excellence is the main guiding planning will facilitate the understanding that the newborn is a developing human being and, after discharge, that individual will need to be able to healthy develop and potentially normal.

\section{Conclusions}

This study showed a significant use of the knowledge received by the nursing staff of the Maternity School of the Federal University of Rio de Janeiro regarding the positioning in NICU beds. The integration of the concepts of humanized global care (intrinsic to the nursing staff) with the further study on the effects of positioning on breathing and motor development (more focused by the physiotherapy team), become the team more homogeneously prepared to perpetuate beneficial effects of various positions with or without the presence of the physiotherapist and in any situation of daily clinical practice. However, further studies are needed to verify the practical impacts of the updates and interdisciplinary actions on the clinical progression of newborns hospitalized to NICU.

\section{References}

1. World Health Organization. Born too soon: the global action report on preterm birth. Geneva: WHO; 2012 [cited 2012 May 25]. Available from: http://apps.who.int/ iris/bitstream/10665/44864/1/9789241503433_ eng.pdf

2. Ibidi S, Cardoso LEMB. Classificação do recém-nascido: cuidados com o RNPIG e RNGIG. In: Vaz FAC, Diniz EMA, Ceccon MEJR, Krebs VLJ. Neonatologia. Barueri: Manole; 2011. p. 3-12. 
3. Nascimento LF. Estudo transversal sobre fatores associados ao baixo peso ao nascer a partir de informações obtidas em sala de vacinação. Rev Bras Saude Mater Infant. 2003;3(1):37-42.

4. Rugolo LM. Crescimento e desenvolvimento a longo prazo do prematuro extremo. J Pediatr. 2005;81(1 Suppl):S101-10.

5. Marlow N, Wolke D, Bracewall MA, Samara M; EPICute Study Group. Neurologic and developmental disability at six years of age after extremely preterm birth. N Engl J Med. 2005;352(1):9-19.

6. De Mello RR, Dutra MV, Ramos JR, Daltro P, Boechat M, Lopes JM. Neonatal risk factors for respiratory morbidity during the first year of life among premature infants. São Paulo Med J. 2006;124(2):77-84.

7. Payne V, Isaacs LD. Desenvolvimento motor humano: uma abordagem vitalícia. Rio de Janeiro: Guanabara Koogan; 2007.

8. Fleming PJ, Muller NL, Bryan MH, Bryan AC. The effects of abdominal loading on rib cage distortion in premature infants. Pediatrics. 1979;64(4):425-8.

9. Heldt GP, McIlroy MB. Dynamics of chest wall in preterm infants. J Appl Physiol. 1987;62(1):170-4.

10. Bhat RY, Leipälä JA, Singh NR, Rafferty GF, Hannam S, Greenough A. Effect of posture on oxygenation, lung volume and respiratory mechanics in premature infants studied before discharge. Pediatrics. 2003;112 (1 Pt 1):29-32.

11. Oliveira TG, Rego MAS, Pereira NC, Vaz LO, França DC, Vieira DSR, et al. Posição PRONA e diminuição da assincronia toracoabdominal em recém-nascidos prematuros. J Pediatr. 2009;85(5):443-8.

12. Johnston C, Zanetti NM, Comaru T, Ribeiro SNS, Andrade LB, Santos SLL. I Recomendação brasileira de fisioterapia respiratória em unidade de terapia intensiva pediátrica e neonatal. Rev Bras Ter Intensiva. 2012;24(2):119-29.

13. Sweeney JK, Swanson MW. Neonatos e bebês de risco: manejo em UTIN e acompanhamento. In: Umphered DA. Fisioterapia neurológica. 2. ed. Barueri: Manole; 1994. p. 181-236.
14. Brasil. Ministério da Saúde. Secretaria de Políticas de Saúde. Área de Saúde da Criança. Atenção humanizada ao recém-nascido de baixo peso: método mãe-canguru: manual do curso. Brasília: Ministério da Saúde; 2002.

15. Vasconcelos GAR, Almeida RCA, Bezerra AL. Repercussões da fisioterapia na unidade de terapia intensiva neonatal. Fisioter Mov. 2011;24(1):65-73.

16. Nicolau CM. Desempenho motor em recém-nascidos pré-termo de alto risco. Rev Bras Crescimento Desenvolv Hum. 2011;21(2):327-34.

17. Willrich A, Azevedo CCF, Fernandes JO. Desenvolvimento motor na infância: influência dos fatores de risco e programas de intervenção. Rev Neurocienc. 2009;17(1):51-6.

18. Lekskulchai R, Cole J. Effect of a developmental program on motor performance in infants born preterm. Aust J Physiother. 2001;47(3):169-76.

19. Harding JE, Milles FKI, Becroft DMO, Allen BC, Knight DB. Chest physiotherapy may be associated with brain damage in extremely premature infants. J Pediatr.1998;132(3 Pt 1):440-4.

20. Gaíva MAM, Scochi CGS. Processo de trabalho em saúde e enfermagem em UTI Neonatal. Rev Lat Am Enfermagem. 2004;12(3):469-76.

21. Liberali J, Davidson J, Santos AMN. Disponibilidade de assistência fisioterapêutica em unidades de terapia intensiva neonatal na cidade de São Paulo. Rev Bras Ter Intensiva. 2014;26(1):57-64.

22. Oliveira BRG, Lopes TA, Vieira CS, Collet N. O processo de trabalho da equipe de enfermagem na UTI neonatal e o cuidar humanizado. Texto Contexto Enferm. 2006;15(n. esp.):105-13.

23. Xavier SO, Nascimento MAL, Badolati MEM, da Paiva MB, de Camargo FCM. Estratégias de posicionamento do recém-nascido prematuro: reflexões para o cuidado de enfermagem neonatal. Rev Enferm UERJ. 2012; 20(esp. 2):814-8.

24. Gouna G, Rakza T, Kuissi E, Pennaforte T, Mur S, Storme L. Positioning effects on lung function and breathing pattern in premature newborns. J Pediatr. 2013;162(6):1133-7. 
25. Cavalier A, Picot MC, Artiaga C, Mazurier E, Amilhau MO, Froye E, et al. Prevention of deformational plagiocephaly in neonates. Early Hum Dev. 2011; 87(8):537-43.

26. Hough JL, Johnston L, Brauer SG, Woodgate PG, Pham TMT, Schibler A. Effect of body position on ventilation distribution in preterm infants on continuous positive airway pressure. Pediatr Crit Care Med. 2012; 13(4):446-51.

27. Chen SS, Tzeng YL, Gau BS, Kuo PC, Chen JY. Effects of prone and supine positioning on gastric residuals in preterm infants: a time series with cross-over study. Int J Nurs Stud. 2013;50(11):1459-67.

28. Nicolau CM, Falcão MC. Influência da fisioterapia respiratória sobre a função cardiopulmonar em recémnascidos de muito baixo peso. Rev Paul Pediatr. 2010; 28(2):170-5.
29. Yagui ACZ, Beppu OS. Effect of prone position without PEEP on oxygenation and complacency in an experimental model of lung injury. J Pediatr. 2007;83(4):343-8.

30. Bhat RY, Leipala JA, Singh NRP. Effect of posture on oxygenation, lung volume and respiratory mechanics in premature infants studied before discharge. Pediatrics. 2003;112(1 Pt 1):29-32.

Received: 09/18/2012

Recebido: 18/09/2012

Approved: 04/01/2015

Aprovado: 01/04/2015 
